\title{
Analisis Strategi Daya Saing (Competitive Advantage) Kopia Karanji Gorontalo
}

\author{
Rifki Mohamad 1), Idris Yanto Niode ${ }^{2)}$ \\ ${ }^{1)}$ Mahasiswa Jurusan Manajemen, Universitas Negeri Gorontalo \\ 2)Dosen Jurusan Manajemen, Universitas Negeri Gorontalo \\ rifkimohamad31@gmail.com
}

\begin{abstract}
This research aims to determine the competitive advantage strategy analysis of Kopia Karanji Gorontalo. The research methode use is a qualitative method. The data analysis technique of this research is identifyng the external and internal factors, EFAS and IFAS Matrix Anaysis, SPACE Matrix Analysis, TOWS Matrix Analysis. The Finding reveals that from the external side Kopia Karanji Gorontalo is in a good category with the total of value is 2.4747 which means (kopia karanji industry) in terms of competitive advantage strategy, it has been utilizing the existing opportunities to minimize the threats. The total score of opportunities is higher than the total score of treatment $(y>0)$ with the difference score between treathment-opportunity for 1.2602. Meanwhile, form the internal side, the industry of kopia karanji Gorontalo also in good category with the total of value is 3.2332 which means (kopia karanji indsutry) in terms of competitive advantage strategy, it has been optimizing to utilize the strenght to decrease the weakness. The total score of strenght is higher than the total score of weakness $(x>0)$ with difference score between strenght-weakness is 0.6068. Furthermore based on the SPACE matrix analysis, kopia karanji industry is in quadrant 1 position (aggressive strategy) by applyng strategy of market penetration, market development, product development, and concentric diversification.
\end{abstract}

Keyword: Competitive Advantage; Analysis TOWS

\section{PENDAHULUAN}

\section{Latar belakang}

Kopiah Karanji atau dalam

istilah masyarakat Gorontalo yaitu

"Upia Karanji" merupakan songkok

khas tradisional Gorontalo yang terbuat dari anyaman batang mintu (sejenis rotan). Kopiah Gorontalo merupakan songkok yang nyaman di kenakan karena sirkulasi udara sangat mudah masuk, sehingga orang-orang sangat menyukai produk khas Gorontalo tersebut.
Sebelumnya di zaman Presiden Republik Indonesia yang ke-tiga Bapak Abdurrahman Wahid atau yang lebih di kenal dengan sapaan Gusdur pernah mempromosikan produk khas Gorontalo itu ke Indonesia dengan istilah peci nusantara. Dilihat dari sejarah, ketika kunjungannya di provinsi Gorontalo tepatnya di Kabupaten Boalemo ada seorang ulama setempat memberikan kopia tersebut kepada beliau dan di kenakannya sampai beliau meninggal. 
Hingga pada akhirnya produk khas Gorontalo tersebut di kenal oleh Masyarakat luas dengan sebutan "Songkok Gusdur" atau "Songkok Nusantara". Ketika ada tamu yang dari luar daerah berkunjung ke Provinsi Gorontalo, pemerintah daerah selalu memberikan kopia tersebut sebagaii cendramata.

Dewasa ini, Kopia karanji sedang mengalami naik daun dengan melihat budaya di Provinsi Gorontalo di mana semua lapisan masyarakat Gorontalo sudah dengan percaya dirinya mengenakan kopia tersebut. Semenjak berlakunya Peraturan Daerah Provinsi Gorontalo Nomor 4 Tahun 2017 tentang pengembangan Kerajinan Karawo Dan Kopia Karanji.

Berangkat dari fenomena tersebut penulis melihat bahwa, hal tersebut menjadi faktor peningkatan penjualan pada industri kerajinan kopia Karanji. Karena dengan berlakunya Peraturan daerah Provinsi Gorontalo banyak pegawai instansi ataupun ASN (Aparatur Sipil Negara) di wajibkan mengenakan kopia tersebut sehingga para ASN saling angat antusias memiliki kopiah khas Gorontalo sebagai upaya melestariakan budaya yang ada di Gorontalo.

Upaya mendukung peraturan provinsi, dari pihak industri meningkatkan produksinya untuk memenuhi kebutuhan permintaan dari pelanggan dengan menciptakan lebih banyak produk khas Provinsi Gorontalo Kopiah Karanji. Untuk itu, dari pihak industri harus memiliki strategi dalam hal untuk meningkatkan penjualan kopiah karanji sebagai upaya untuk mendukung kebijkan pemerintah.
Dalam perkembangan dunia usaha sekarang ini tingkat persaingan industri semakin tajam, walaupun industri kopiah karanji masih pada tataran lokal daerah. Dengan semakin majunya perkembangan teknologi sekarang ini, industri kopiah karanji harus bisa berusaha mengedapankan daya saing dengan menekan kualitas produksi yang bertujuan memaksimalkan keuntungankeuntungan sesuai dengan target industri kopiah karanji.

Pembahasan tentang daya saing perusahaan sudah lama menggemukan, banyak definisi diberikan berkaitan dengan daya saing ini. Beberapa ahli menyebutkan bahwa: daya saing merupakan fungsi identifikasi dimensi produk pasar yang tepat bagi potitioning perusahaan (Ansoff dalam Hameed, 2009). Demikian pula Porter (1985) dalam bukunya menyatakan bahwa daya saing sebagai upaya penciptaan nilai pelanggan yang lebih baik dibandingkan pesaingnya dengan cara melakuka aktivitas-aktivitas spesifik secara ekonomis ataupun kualitas superior/pelayanan ataupun kombinasi keduanya dibandingkan dengan para kompetitornya.

Daya saing dapat juga berasal dari sumber daya yang dimiliki perusahaan. Perspektif ini dikenal dengan Resourch Based View (RBV) atau perspektif berbasis sumber daya yang dicetuskan oleh Penrose (1959) dalam Hameed (2009). Menurutnya, daya saing dapat dicapai dengan skala ekonomis, meningkatkan kapabilitas manajemen dan kapasitas teknologi (Penrose, 1959 dalam Hameed,2009). 
Citra yang baik serta kepercayaan terhadap indutri pembuatan kopiah karanji akan membuat konsumen terpikat untuk mengadakan pembelian ulang atau loyal terhadap produk dan konsumen tidak akan beralih pada industri lain yang juga menawarkan produk yang sejenis.

Bagi industri kopiah karanji hal ini akan mempermudah penentuan kebijakan dalam menerapkan strategi atau teknik analisa, sejalan dengan berkembangnya teknologi pada saat ini. Industri kopia karanji harus mampu menganalisa lingkungan pasar. Karena dengan hanya terfokus pada peningkatan kualitas produk dan berupaya besar untuk mendapatkan keuntungan tidak cukup untuk memperpanjang industri yang masih berada pada tataran lokal daerah yang nantinya akan berhadapan dengan pesaing (competitor). Olehnya, industri harus memiliki strategi dalam menganalisa pasar sebagai upaya menjaga konsistensi dalam hal aktivitas dagang industri.

Merujuk pada masalah dan strategi pemasaran yang diterapkan pemilik industri, seharusnya analisis TOWS merupakan solusi ataupun senjata yang mestinya digunakan. Analisis TOWS adalah satu-satunya pisau ataupun alat bedah yang dilakukan oleh beberapa perusahan atau industri sebagai upaya untuk mengangalisa lingkungan pasar entah dari dalam maupun dari luar. Pemilik industri harus mampu menyesuaikan dengan keadaan dan bisa membaca kondisi pasar dalam hal ini adalah industri yang memproduksi kopia karanji.
Berupaya menjadikan indutri yang jangka panjang, pemilik industri juga bisa menganalisa lingkungan luar pasar seperti ancaman, peluang dan juga dari lingkungan dalam pasar seperti kelemahan dan kekuatan. Dengan menggunakan pisau analisa TOWS, pemilik indutrsi mampu membaca segala keadaan entah kelebihan maupun kekurangan industri.

Tujuan penulisan penelitian ini yaitu untuk mengetahui strategi daya saing produk kopiah karanji Gorontalo ditinjau dari metode analisis TOWS".

\section{KAJIAN TEORI}

\section{Pengertian Strategi}

Menurut Rangkuti (2002: 13) strategi merupakan alat untuk mencapai tujuan perusahaan dalam kaitannya dengan tujuan jangka panjang, program tindak lanjut,serta prioritas alokasi sumber daya. Sedangkan menurut David (2006: 18) strategi adalah sarana bersama dengan tujuan jangka panjang hendak dicapai. Strategi akan memaksimalkan keunggulan kompetitif dan meminimalkan keterbatasan bersaing.

\section{Tingkatan Strategi}

Dalam manajemen strategi, perusahaan pada umumnya mempunyai tiga level atau tingkatan strategi, yaitu:

1. Strategi Korporasi

Strategi ini berusaha mengeksploitasi kompetensi khusus perusahaannya dengan mengadopsi pendekatan portofolio terhadap manajemen bisnisnya dan mengembangkan rencana jangka panjang, umumnya untuk periode tiga sampai lima tahu. 
2. Strategi unit bisnis

Strategi ini bisa dikembangkan pada leve divisi dan menekankan pada perbaikan posisi persaingan produk barang atau jasa perusahaan dalam industrinya atau segmen pasar yang dilayani oleh divisi tersebut. Strategi bisnis uang diimplementasikan biasanya merupakan salah satu startegi overall cost leadrship, atau diferensiasi.

3. Strategi fungsional

Strategi ini menekenkan terutama pada pemaksimal sumber daya produktivitas. Dalam batasan oleh perusahaan dan strategi bisnis yang berada pada sekitar mereka, departemen fungsional seperti fungsi-fungsi pemasaran, SDM, keungan, produk-operasi mengembangkan strategi untuk mengumpulkan bersama-sama berbagai aktivitas dan kompetensi mereka guna meningkatkan kinerja peusahaan.

Menurut Davd Hunger dan Thomas wheelen yang menyatakan bahwa:"Strategi terdiri atas strategi korporasi menggambarkan arah perusahaan terhadap arah pertumbuhan dan manajemen berbagai bisnis dan ini untuk mencapai keseimbangan produk dan jasa, strategi bisnis bersaing menggambarkan segmen pasar yang dilayani devisi tersebut, dikembangkan pada level divisi, dan menekan pada perbaikkan posisi pesaing produk barang atau jasa perusahaan dalam industri khusus, stragei fungsional menekankan pada pemaksimalan sumber daya produktivitas perusahaan dan strategi bisnis di sekitar mereka".

\section{Pengertian Pesaing (Competitior)}

Pesaing adalah suatu

perjuangan yang dilakukan oleh seseorang atau kelompok orang tertentu, agar memperoleh kemenangan atau hasil secara kompetitif, tanpa menimbulkan ancaman atau benturan fisik di pihak lawannya.

Menurut Body, Walker dan Larrech dalam buku manajemen pemasaran menyatakan bahwa: "Pesaing adalah struktur industri, sepak terjang berbagai kekuatan pesaing yang mempengaruhi kemampuan labaan dalam industri".

Pengertian Daya saing (Competitive Advantage)

Menurut Crown Dirgantoro daya saing adalah perkembangan dari nilai yang mampu diciptakan perusahaan untuk membelinya. Menurut Agustinus Sri Wahyadi memberikan pengertian bahwa keunggulan bersaing adalah sesuatu yang memungkinkan sebuah perusahaan memperoleh keuntungan yang lebih tinggi dibandingkan dengan rata-rata keunggulan yang diperoleh pesaing dalam industri.

\section{Strategi Bersaing Generik}

Ada sejumlah strategi yang sudah banyak diketahui umum dan dapat diterapkan pada berbagai bentuk industri dan ukuran perusahaan. Strategi-strategi ini dikelompokkan dalam strategi generik generik. Istilah strategi generik di kemukakan oleh Porter.

Pengertiannya adalah suatu pendekatan strategi perusahaan dalam rangka mengungguli pesaing dalam industri sejenis. Dalam praktek, setelah perusahaan mengetahui startegi 
generiknya, untuk impelementasinya akan ditindaklanjuti dengan langkah penentuan strategi yang lebih operasional.

\section{Dimensi Daya Saing}

Dimensi daya saing suatu perusahaan sebagaimana dikemukakan oleh Muhardi (2007:40) dengan mengutip Ward et all (1998:1036-1037) adalah terdiri biaya (cost), kualitas (quality), waktu penyampaian (delivery, dan fleksibilitas (flexibility). Keempat dimensi tersebut lebih lanjut diterangkan oleh Muhardi (2007:41) Lengkap dengan indikatornya sebagai berikut:

1. Biaya adalah dimensi daya saing operasi yang meliputi empat indikator yaitu biaya produksi, produktifitas tenaga kerja, penggunaan kapasitas produksi dan persediaan. Unsur daya saing yang terdiri dari biaya merupakan modal mutlak yang dimiliki oleh suatu perusahaan yang mencakup pembiyaan produksinya, produktifitas tenaga kerja, pemanfaatan kapasitas produksi perusahaan dan adanya cadangan produksi (pesediaan) yang sewaktu-waktu dapat dipergunakan oleh perushaan untuk menunjang kelancaran perusahaan tersebut.

2. Kualitas seperti yang dimaksud oleh Muhardi adalah merupakan dimensi daya saing yang juga sangat penting, yaitu meliputi berbagai indikator diantaranya tampilan produk, jangka waktu penerimaan produk, daya tahan produk, kecepatan penyelesaian keluhan konsumen dan kesesuaian produk terhadap spesifikasi desain.
Tampilan produk dapat tercermin dari desain produk atau layanannya, tampilan produk yang baik adalah yang memiliki desain sederhana namumn mempunyai nilai yang tinggi. Jangka waktu penerimaan produk dimaksudkan dengan lamanya umur produk dapat diterima oleh pasar, semakin lama umur produk di pasar menunjukan kualitas produk tersebut semakin baik. Adapun daya tahan produk dapat diukur dari umur ekonomis penggunaan produk.

3. Waktu penyampaian merupakan dimensi daya saing yang meliputi berbagai indikator diantaranya ketetapan waktu produksi, pengurangan waktu tunggu produksi dan ketetapan waktu penyampaian produk dapat. Ketiga indikator tersebut berkaitan, ketetapan waktu penyampaian produk dapat dipengaruhi oleh ketetapan waktu dan lamanya waktu tunggu produksi.

4. Adapun fleksibel merupakan dimensi daya saing operasi yang meliputi berbagai indikator diantaranya macam produk yang dihasilkan, kecapatan menyesuaikan dengan kepentingan lingkungan.

\section{Startegi Bersaing dalam Menciptakan} Daya Saing

Menurut David (2006) daya saing (Competitive Advantage) merupakan segala sesuatu yang dilakukan dengan sangat baik oleh sebuah perusahaan dibanding dengan pesaingnya. Ketika sebuah perusahaan dapat melakukan sesuatu dan perusahaan lainnya tidak dapat, atau 
memiliki sesuatu yang diinginkan pesaingnya, hal tersebut menggambarkan keunggulan kompetitif sangat penting untuk keberhasilan jangka panjang dari suatu organisasi.

Umumnya, sebuah perusahaan mampu untuk mempertahanakan keunggulan kompetitif hanya untuk periode tertentu karena ditiru pesaing dan melemahnya keunggulan tersebut. Di samping itu startegi bersaing itu sendiri adalah kombinasi antara akhir (tujuan) yang diperjuangkan oleh perusahaan dimana perusahaan berusaha sampai pada tujuan (Porter, 1980).

\section{Analisis SWOT}

SWOT adalah singkatan yang diambil dari huruf depan kata Strength, Weakness, Opportunity dan Threat, yang dalam bahasa Indonesia diartikan sebagai Kekuatan, Kelemahan, Peluang dan Ancaman. Metode analisis SWOT bisa dianggap sebagai metode analisis yang paling dasar, yang berguna untuk melihat suatu topik atau permasalahan dari empat sisi yang berbeda.

Hasil analisa biasanya adalah rekomendasi untuk mempertahankan kekuatan dan menambah keuntungan dari peluang yang ada, sambil mengurangi kekurangan dan menghindari ancaman. Jika digunakan dengan benar, analisis SWOT akan membantu perusahaan untuk melihat sisi-sisi yang terlupakan atau tidak terlihat oleh perusahaan itu sendiri.

\section{Tujuan Penerapan SWOT pada Perusahaan}

Penerapan SWOT pada suatu perusahaan bertujuan untuk memberikan suatu panduan agar perusahaan menjadi lebih fokus, sehingga dengan penempatan analisa SWOT tersebut nantinya dapat dijadikan sebagai bandingan pikir dari berbagai sudut panadang, baik dari segi kekuatan dan kelemahan serta peluang dan ancaman yang mungkin bisa terjadi di masa-masa yang akan datang.

Tujuan lain diperlukannya analisis SWOT adalah dimana setiap produk yang beredar dipasaran pasti akan mengalami pasang surut dalam penjualan atau yang dikenal dengan istilah daur hidup produk (life cycle product).

\section{METODE PENELITIAN \\ Jenis Penelitian}

Jenis metode penelitian yang dilakukan adalah metode penelitian kualitatif dengan pendekatan deskriptif. Peneliti memilih menggunakan metode penelitian kualitatif untuk menentukan cara mencari, mengumpulkan, mengolah dan menganalisis data hasil penelitian tersebut. Penelitian kualitatif ini dapat digunakan untuk memahami interaksi sosial, misalnya dengan wawancara mendalam sehingga akan ditemukan pola-pola yang jelas.

\section{Analisis Data}

Berdasarkan tujuan penelitian yang ingin dicapai yaitu untuk mengetahui permasalahan apa saja yang dihadapi oleh pemilik industri kopia karanji dalam hal memperoleh daya saing. Untuk menganalisis faktorfaktor tersebut dalam merumuskan strategi daya saing kopia karanji dengan menggunakan pedekatan analisis TOWS. Analisis TOWS didasarkan pada logika yang dapat memaksimalkan peluang (opportunities) 
dan kekuatan (strenght), namun secara bersamaan dapat meminimalkan ancaman (threats) dan kelemahan (weakness) (Freddy Rangkuti 2005).

\section{HASIL DAN PEMBAHASAN}

\section{Identifikasi}

Lingkungan

Faktor-Faktor

Lingkungan Internal

Berikut adalah hasil wawancara dan obesrvasi terkait dengan faktorfaktor lingkungan eksternal (ancaman dan peluang) pada tabel berikut ini:

Tabel 1. Identifikasi faktor-faktor lingkungan eksternal

\begin{tabular}{|c|c|}
\hline $\begin{array}{c}\text { Uraian Lingkungan } \\
\text { Eksternal }\end{array}$ & $\begin{array}{c}\text { Hasil Identifikasi } \\
\text { TOWS }\end{array}$ \\
\hline \multirow[t]{3}{*}{ Ancaman (Treath) } & $\begin{array}{l}\text { Adanya persaingan } \\
\text { dari industri lain } \\
\text { yang sejenis (bahan } \\
\text { baku rotan \& Lidi) } \\
\text { (T) }\end{array}$ \\
\hline & $\begin{array}{l}\text { Bahan baku yang } \\
\text { digunakan semakin } \\
\text { langka }(\mathbf{T})\end{array}$ \\
\hline & $\begin{array}{l}\text { Promosi pesaing } \\
\text { lebih kreatif dan } \\
\text { inovatif }(\mathbf{T})\end{array}$ \\
\hline \multirow{3}{*}{$\begin{array}{c}\text { Peluang } \\
\text { (Opportunities) }\end{array}$} & $\begin{array}{l}\text { Terbukanya peluang } \\
\text { kerjasama dengan } \\
\text { pihak lain }(\mathbf{O})\end{array}$ \\
\hline & $\begin{array}{l}\text { Produk kerajinan } \\
\text { yang mulai dikenal } \\
\text { di tingkat Nasional } \\
\text { (O) }\end{array}$ \\
\hline & $\begin{array}{l}\text { Dukungan } \\
\text { Pemerintah Provinsi } \\
\text { dan Kabupaten }\end{array}$ \\
\hline
\end{tabular}

\begin{tabular}{|l|l|}
\hline \multirow{1}{*}{} & (perizinan) (O) \\
\cline { 2 - 3 } & $\begin{array}{l}\text { Bahan baku yang } \\
\text { diperoleh secara } \\
\text { gratis/ Cuma-Cuma } \\
(\mathbf{O})\end{array}$ \\
\cline { 2 - 3 } & $\begin{array}{l}\text { Akses permodalan } \\
\text { terbuka luas dan } \\
\text { mudah di akses (O) }\end{array}$ \\
\cline { 2 - 3 } & $\begin{array}{l}\text { Memiliki pelanggan/ } \\
\text { Pasar yang luas } \\
(\mathbf{O})\end{array}$ \\
\hline
\end{tabular}

Sumber: Hasil wawancara dan observasi diolah. 2019

Selanjutnya adalah hasil wawancara dan obesrvasi terkait dengan faktor-faktor lingkungan internal (kelemahan dan kekuatan) dapat dilihat pada tabel berikut ini:

Tabel 2. Identifikasi faktor-faktor lingkungan internal

\begin{tabular}{|c|c|}
\hline $\begin{array}{c}\text { Uraian Lingkungan } \\
\text { Internal }\end{array}$ & $\begin{array}{c}\text { Hasil Identifikasi } \\
\text { TOWS }\end{array}$ \\
\hline \multirow{5}{*}{$\begin{array}{l}\text { Kelemahan } \\
\text { (Weakness) }\end{array}$} & $\begin{array}{l}\text { Modal usaha yang } \\
\text { terbatas }(\mathbf{W})\end{array}$ \\
\hline & $\begin{array}{l}\text { Minimnya bahan baku } \\
\text { (W) }\end{array}$ \\
\hline & $\begin{array}{l}\text { Lokasi kerajinan } \\
\text { (industri) jauh dari } \\
\text { Bahan baku }(\mathbf{W})\end{array}$ \\
\hline & $\begin{array}{l}\text { Kurangnya perhatian } \\
\text { PEMDA (Modal } \\
\text { Usaha \& Pelatihan) } \\
\text { (W) }\end{array}$ \\
\hline & $\begin{array}{l}\text { Sumber daya } \\
\text { pengrajin yang terlatih } \\
\text { dan Kurangnya } \\
\text { pemahaman } \\
\text { manajemen usaha }\end{array}$ \\
\hline
\end{tabular}




\begin{tabular}{|c|c|}
\hline & $\begin{array}{l}\text { (Pemasaran, promosi, } \\
\text { keuangan dan lain- } \\
\text { lain) }(\mathbf{W})\end{array}$ \\
\hline & $\begin{array}{l}\text { Tidak memiliki izin } \\
\text { usaha }(\mathbf{W})\end{array}$ \\
\hline \multirow{6}{*}{ Kekuatan (Strenght) } & $\begin{array}{l}\text { Sumber daya } \\
\text { pengrajin yang cukup } \\
\text { banyak (S) }\end{array}$ \\
\hline & $\begin{array}{l}\text { Kualitas produk yang } \\
\text { baik }(\mathbf{S})\end{array}$ \\
\hline & $\begin{array}{l}\text { Kapasitas Produksi } \\
\text { yang cukup banyak } \\
\text { (S) }\end{array}$ \\
\hline & $\begin{array}{l}\text { Harga produk } \\
\text { kompetitif (S) }\end{array}$ \\
\hline & $\begin{array}{l}\text { Sumber daya } \\
\text { pengrajin yang terlatih } \\
\text { dan terampil (S) }\end{array}$ \\
\hline & $\begin{array}{l}\text { Produk inovatif dan } \\
\text { dibuat sesuai selera } \\
\text { konsumen/ pasar (S) }\end{array}$ \\
\hline
\end{tabular}

Sumber: Hasil wawancara dan observasi diolah. 2019 Tahap analisis EFAS dan IFAS

Tahap ini merupakan tahapan lanjutan pertama setelah identifikasi faktor-faktor eksternal dan internal tersebut. Maka disusunlah Matriks EFAS (Eksternal Factor Analysis Strategic) dan Matriks IFAS (Internal Factor Analysis Strategic) yang akan dibahas sebagai berikut:
Tabel 3. EFAS (Eksternal Faktor Analysis Summary) strategi daya saing kopia karanji Gorontalo

\begin{tabular}{|c|c|c|c|c|c|}
\hline & $\begin{array}{c}\text { Faktor Strategi } \\
\text { Eskternal }\end{array}$ & Bobot & $\begin{array}{c}\text { Pering } \\
\text { kat }\end{array}$ & $\begin{array}{c}\text { Skor } \\
\text { Terbobot }\end{array}$ & $\begin{array}{l}\mathbf{K} \\
\mathbf{e} \\
\mathbf{t}\end{array}$ \\
\hline $\begin{array}{l}\text { An } \\
* \\
* \\
*\end{array}$ & $\begin{array}{l}\text { aman (Treath) } \\
\text { Adanya persaingan } \\
\text { dari industri lain } \\
\text { yang sejenis (bahan } \\
\text { baku rotan \& Lidi) } \\
\text { Bahan baku yang } \\
\text { digunakan semakin } \\
\text { langka } \\
\text { Promo pesaing } \\
\text { lebih kreatif dan } \\
\text { inovatif }\end{array}$ & $\begin{array}{l}0.1132 \\
0.1096 \\
0.0915\end{array}$ & $\begin{array}{l}1 \\
2 \\
3\end{array}$ & $\begin{array}{r}0.1132 \\
0.2192 \\
0.274\end{array}$ & \\
\hline To & al Skor Ancaman & 0.3144 & & 0.6072 & \\
\hline $\begin{array}{l}\text { Pel } \\
* \\
* \\
* \\
* \\
* \\
*\end{array}$ & $\begin{array}{l}\text { Tang (Opportunities) } \\
\text { Terbukanya } \\
\text { peluang kerjasama } \\
\text { dengan pihak lain } \\
\text { Produk kerajinan } \\
\text { yang mulai dikenal } \\
\text { di tingkat Nasional } \\
\text { Dukungan } \\
\text { Pemerintah } \\
\text { Provinsi dan } \\
\text { Kabupaten } \\
\text { (perizinan) } \\
\text { Bahan baku yang } \\
\text { diperoleh secara } \\
\text { gratis/ Cuma-Cuma } \\
\text { Akses permodalan } \\
\text { terbuka luas dan } \\
\text { mudah di akses } \\
\text { Memiliki } \\
\text { pelanggan/ Pasar } \\
\text { yang luas }\end{array}$ & $\begin{array}{r}0.1132 \\
0.1120 \\
0.1156 \\
0.124 \\
0.1120 \\
0.1084\end{array}$ & $\begin{array}{l}3 \\
1 \\
4 \\
5 \\
2 \\
1\end{array}$ & $\begin{array}{r}0.3397 \\
0.1120 \\
0.4626 \\
0.6204 \\
0.224 \\
0.1084\end{array}$ & \\
\hline \multicolumn{2}{|c|}{ Total Skor Peluang } & 0.6855 & & 1.8674 & \\
\hline \multicolumn{2}{|c|}{ Jumlah } & 1 & & 2.4747 & \\
\hline \multicolumn{2}{|c|}{$\begin{array}{l}\text { Selisih Peluang- } \\
\text { Ancaman }\end{array}$} & \multicolumn{3}{|c|}{1.260240} & \\
\hline
\end{tabular}

Sumber: Hasil wawancara dan observasi diolah. 2019

Berdasarkan EFAS matriks pada tabel 3 di atas terlihat bahwa posisii sektorsektor industri kopia karanji menyangkut strategi daya saingnya berada pada posisi realitf baik dalam menghadapi lingkungan eksternalnya dengan total nilai 2.4747 dengan demikian sektor ini (industri kopia karanji Gorontalo) dalam hal strategi daya saingnya telah memanfaatkan peluang yang ada untuk meminimalisir ancaman yang terkait dengan strategi daya saing kopia karanji. 
Selanjutnya pada tabel 3 di atas dapat djelaskan total skor peluang lebih besar daripada total skor ancaman $(\mathrm{y}>0)$ dengan selisih total skor peluang-ancaman sebesar 1.2602. Data diperoleh berdasarkan hasil wawancara dan hasil angket, bahwa faktor peluang lebih besar daripada ancaman.

Tabel 4. IFAS (Internal Factor Analysis Summary) Strategi daya saing kopia karanji Gorontalo

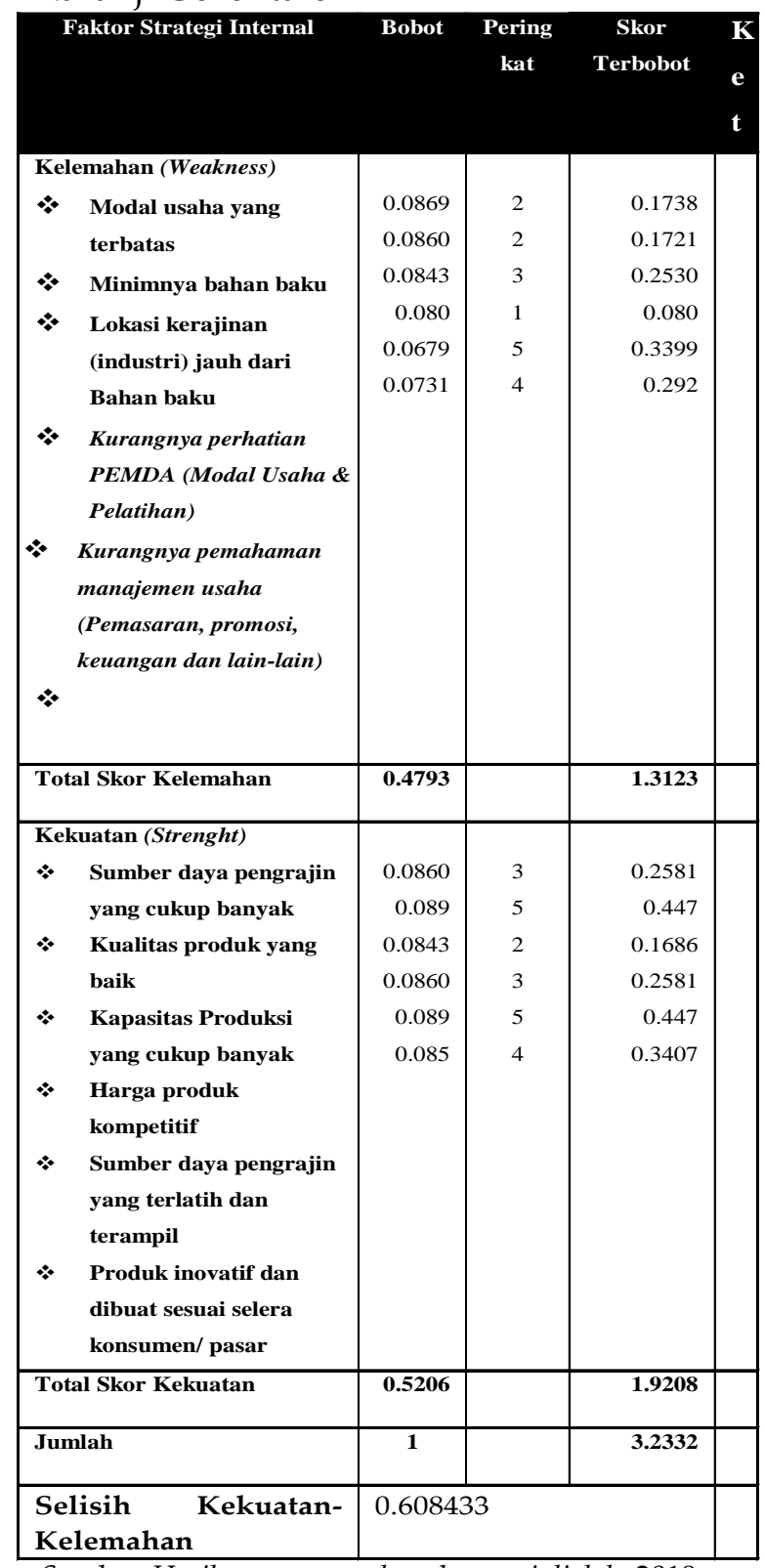

Sumber: Hasil wawancara dan observasi diolah. 2019
Berdasarkan IFAS matriks pada tabel 4 diatas terlihat bahwa posisi sektor-sektor industri kopia karanji menyangkut strategi daya saingnya, berada pada posisis relatif baik dalam menghadapi lingkungan internalnya dengan total nilai 3.2332. Dengan demikian sektor ini ( industri kopia karanji) dalam hal strategi daya saing telah mencoba seoptimal mungkin untuk memanfaatkan kekuatan untuk mengurangi kelemahan.

Selanjutnya tabel 4 di atas dapat dijelaskan total skor kekuatan lebih besar daripada total skor kelemahan ( $\mathrm{x}$ $>0$ ) dengan selisih total skor kekuatankelemahan sebesar 0.6084. Data diperoleh berdasarkan hasil wawancara dan hasil angket, bahwa faktor kekuatan lebih dominan daripada kelemahan.

Matriks SPACE (Strategic Position and Action Evaluation)

Gambar 1. Matriks Posisi strategi daya saing industri kopia karanji Gorontalo.

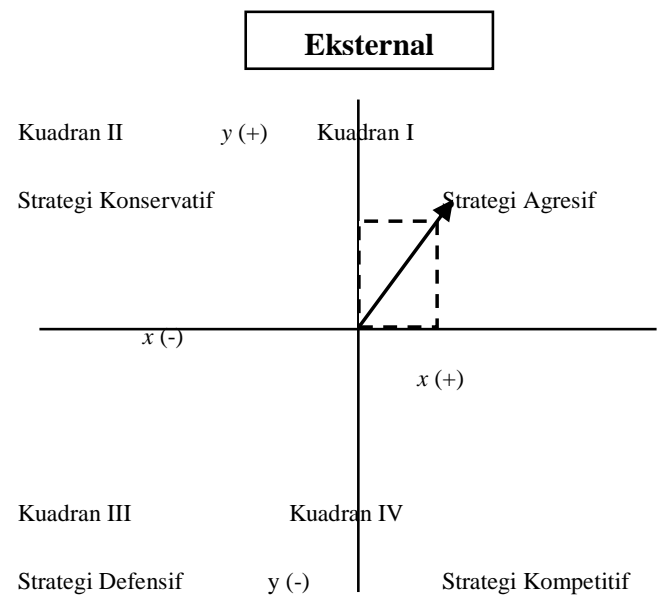

Berdasarkan gambar diagram diatas maka dapat dijelaskan posisi industri kopia karanji dalam hal ini pemilik industri harus mampu meningkatkan daya saing dengan menerapakan startegi agresif. 


\section{Matriks TOWS}

Matriks TOWS Analisis strategi daya saing kerajinan kopia karanji Gorontalo di Desa Pulubala Kecamatan Pulubala Kabupaten Gorontalo

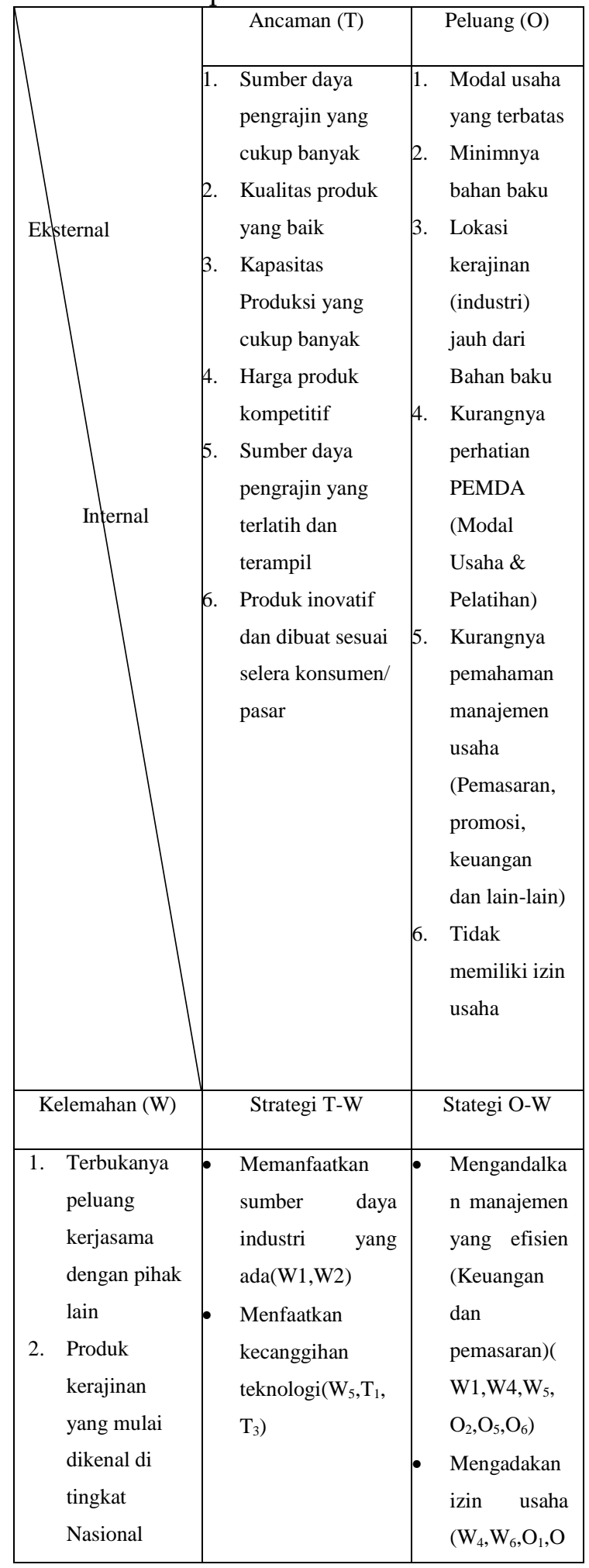

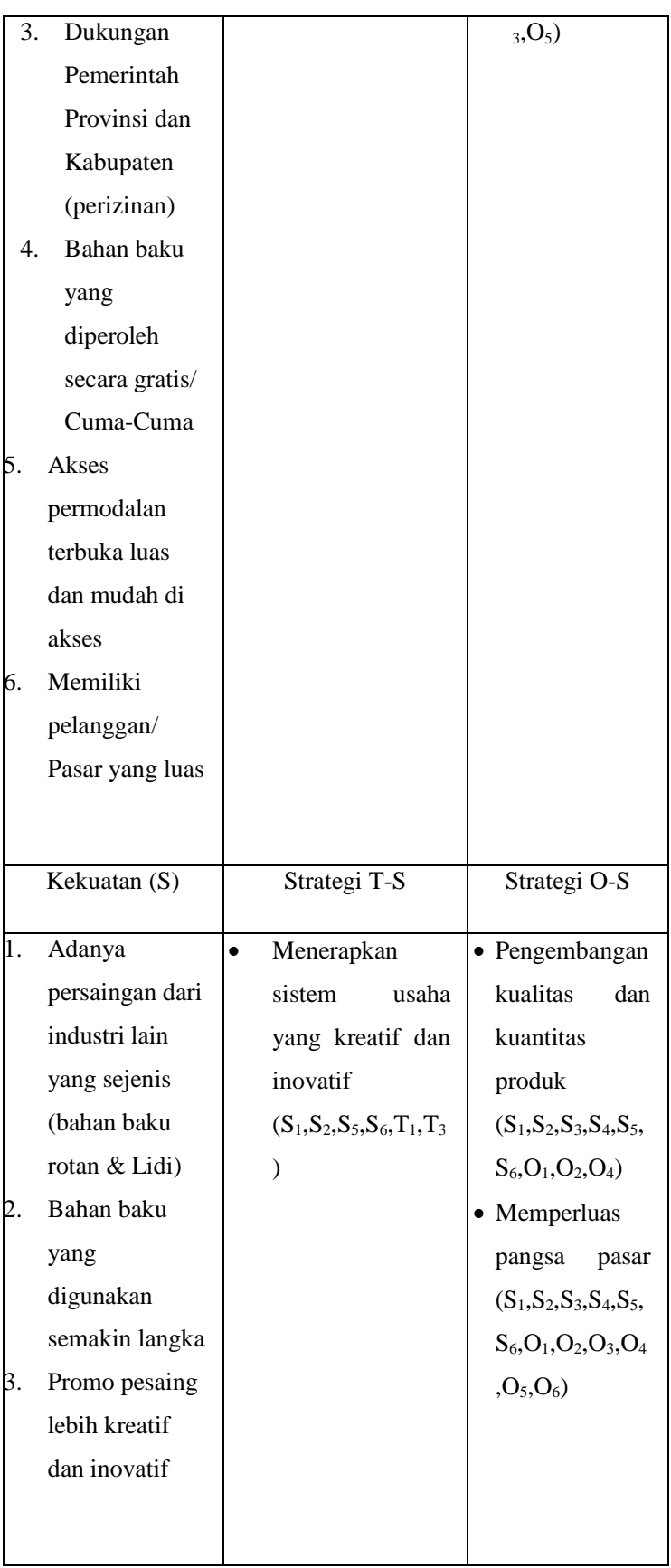

Sumber: Hasil wawancara dan observasi diolah. 2019

\section{Pembahasan}

Berikut adalah startegi yang harus diterapkan oleh industri kopia karanji Gorontalo di Desa Pulubala Kecamatan Pulubala yang berada pada posisi kuadran agresif.

\section{Market Penetration}

Market penetration atau penetrasi pasar adalah strategi yang diberikan 
kepada industri untuk meningkatkan pertumbuhan di mana industri berfokus pada penjualan produk di pasar yang telah ada sebelumnya. Industri kopia karanji yang berada di Desa Pulubala mempertahankan dan meningkatkan pangsa pasar produk dengan mengkombinasikan strategi harga yang kompetitif, dan mampu memanfaatkan kecanggihan teknologi yang ada sebagai alat promosi.

2. Market Development

Market Development atau pengembangan pasar merupakan strategi yang harus digunakan oleh industri kopia karanji dimana pemiliknya selalu berusaha untuk menjual produk kopia karanji dipasar-pasar yang baru dengan menerapkan kebijakan harga untuk menarik pelanggan baru.

3. Product Development

Product Development atau Pengembangan produk yang merupakan strategi pertumbuhan di mana industri kopia karanji memperkenalkan inovasi produk baru ke pasar-pasar yang telah ada. Hal ini memerlukan strategi pengembangan kompetensi baru dan memerlukan program pemasaran yang baru untuk mengembangkan produk kopia karanji.

4. Concentric Diversification

Concentric Diversification merupakan strategi yang harus diterapan oleh industri kopia karanji dimana strategi ini harus mengembangkan inovasi baru dari kopia karanji. Strategi ini harus diterapkan karena Industri kopia karanji di Desa
Pulubala memiliki ancaman berupa adanya pendatang baru dengan memproduksi prduk yang sama tetapi dengan bahan baku yang berbeda.

Selanjutnya untuk mendukung grand strategy di atas, maka dilakukan perumusan strategi TOWS. Matriks Treath-Opportunities-Weakness-Strenght (TOWS) merupakan matching cool yang penting untuk membantu pemilik industri untuk mengembangkan empat jenis strategi. Berikut adalah kategori strategi menurut matriks TOWS (Umar,2008:224).

1. Strategi TW (Treath-Weaknes)

Strategi ini merupakan taktik untuk bertahan dengan cara mengurangi kelemahan internal serta menghindari ancaman-ancaman dari luar. Strategi alternatif yang perlu dilakukan adalah memanfaatkan sumber daya industri yang ada (W1,W2) dan juga memanfaatkan kecanggihan teknologi $\left(\mathrm{W}_{5}, \mathrm{~T}_{1}, \mathrm{~T}_{3}\right)$.

2. Strategi OW (Opportuniy-Weakness)

Strategi ini bertujuan untuk memperkecil kelemahan-kelemahan internal perusahaan dengan memanfaatkan peluang-peluang eksternal. Strategi alternatif yang lakukan adalah mengandalkan manajemen yang efisien (keuangan dan pemasaran) $\left(\mathrm{W} 1, \mathrm{~W} 4, \mathrm{~W}_{5}, \mathrm{O}_{2}, \mathrm{O}_{5}, \mathrm{O}_{6}\right) \quad$ serta mengadakan izin usaha $\left(\mathrm{W}_{4}, \mathrm{~W}_{6}, \mathrm{O}_{1}, \mathrm{O}_{3}, \mathrm{O}_{5}\right)$.

3. Strategi TS (Threath-Strenght)

Melalui strategi ini industri kopia karanji akan berusaha untuk menghindari atau mengurangi dampak dari ancaman-ancaman eksternal. Strategi yang harus diterapkan adalah menerapkan 
sistem usaha yang kreatif dan inovatif $\left(\mathrm{S}_{1}, \mathrm{~S}_{2}, \mathrm{~S}_{5}, \mathrm{~S}_{6}, \mathrm{~T}_{1}, \mathrm{~T}_{3}\right)$.

4. Strategi OS (Opportunity-Strenght)

Strategi ini memanfaatkan peluang ekstetanl industri kopia karanji untuk dijadikan kekuatan yang ada di dalam industri. Adapun startegi alternatif yang perlu diterapkan industri kopia karanji adalah pengembangan kualitas dan kuantitas produk $\left(\mathrm{S}_{1}, \mathrm{~S}_{2}, \mathrm{~S}_{3}, \mathrm{~S}_{4}, \mathrm{~S}_{5}, \mathrm{~S}_{6}, \mathrm{O}_{1}, \mathrm{O}_{2}, \mathrm{O}_{4}\right)$ dan juga memperluas pangsa pasar $\left(\mathrm{S}_{1}, \mathrm{~S}_{2}, \mathrm{~S}_{3}, \mathrm{~S}_{4}, \mathrm{~S}_{5}, \mathrm{~S}_{6}, \mathrm{O}_{1}, \mathrm{O}_{2}, \mathrm{O}_{3}, \mathrm{O}_{4}, \mathrm{O}_{5}, \mathrm{O}_{6}\right)$.

\section{PENUTUP}

\section{Kesimpulan}

Berdasarkan hasil analisis eksternal, diketahui faktor-fakor ancaman, peluang, kelemahan dan kekuatan dalam strategi daya saing kopia karanji Gorontalo di Desa Pulubala Kecamatan Pulubala Kabupaten Gorontalo, yaitu:

1. Ancaman (Treath): a). Adanya persaingan dari industri lain yang sejenis (bahan baku rotan dan lidi); b). Bahan baku yang digunakan semakin langkah; c). Promo pesaing lebih kreatif dan inovatif.

2. Peluang (Opportunities): a). Terbukanya peluang kerja sama dengan pihak lain; b). Produk kerajinan yang mulai dikenal di tingkat nasioanal; c). Dukungan Pemerintah Provinsi dan Kabupaten (perizinan); d).Bahan baku yang diperoleh secara gratis atau cumaCuma; e). Akses permodalan terbuka luas dan mudah diakses; f). Memiliki pelanggan/pasar yang luas.

3. Kelemahan (Weakness): a). Modal usaha yang terbatas; b). Minimnya bahan baku; c). Lokasi kerajinan (industri) jauh dari bahan baku; d). Kurangnya perhatian PEMDA (modal usaha dan pelatihan); e). Kurangnya pemahaman manajemen usaha (pemasaran, promosi, keuangan dan lain-lan); f). Tidak memiliki izin usaha.

4. Kekuatan (Strenght): a). Sumber daya pengrajin yang cukup banyak; b). Kualitas produk yang baik; c). Kapasitas Produksi yang cukup banyak; d). Harga produk kompetitif; e). Sumber daya pengrajin yang terlatih dan terampil; f). Produk inovatif dan dibuat sesuai selera konsumen/ pasar.

5. Grand Strategy yang dapat digunakan adalah kuadran agresif. Di mana strategi yang dapat diterapkan adalah market penetration, market development, product development serta concentric diversification.

Perumusan strategi melalui matriks TOWS diperoleh alternatif sebagai berikut: a). Memanfaatkan sumber daya industri yang ada dan memanfaatkan kecanggihan teknologi; b). Mengandalkan manajemen yang efisien (keuangan dan pemasaran) dan mengadakan izin usaha; c). Menerapkan sistem usaha yang kreatif dan inovatif; d). pengembangan kualitas dan kuantitas produk dan memperluas pangsa pasar.

\section{Saran}

Saran yang dapat disampaikan dalam rangka mengembangkan usaha kopia karanji Gorontalo khususnya pada startegi daya saing (competitive advantage):

1. Sebagai bentuk untuk mempertahankan roda usaha kerajinan kopia karanji maka 
beberapa faktor yang didapatkan dalam penelitian harus diperhatikan dan menjadi suatu pegangan untuk mengembangkan usaha kopia karanji.

2. Terus memproduksi kopia karanji dengan harga yang lebih kompetitif agar bisa memiliki pangsa pasar dan juga sebagai bentuk melestarikan budaya Provinsi Gorontalo

3. Selalu melakukan inovasi baru dari kopia karanji untuk tetap diminati oleh banyak orang baik lokal maupun nasional.

\section{DAFTAR PUSTAKA}

Arikunto, Suharsimi. 2011. Prosedur Penelitian suatu pendekatan praktik. Rineka Cipta. Jakarta.

Bennett, Robert J. dan Colin Smith. 2002. Competitive, Condition, Competitive Advantage And The Location Of SME's. Journal of Small Business and Enterprise Development. Vol 9:1. MCB University Press. Pp. 73-86.

Bishop, Paul dan Phill Megicks. 2002. Competitive Strategy And Firm Size In The Estate Agency Industry. Journal of Small Business and Enterprise Development Vol 9:2. MCB University Press. pp. 150-161

Bungin, M. Burhan. 2007. Penelitian Kualitatif: Komunikasi, Ekonomi, Kebijakan Publik, dan Ilmu Sosial Lainnya. Jakarta: Kencana Prenada Media Group.

David, Fred R. 2003. Strategy Management Concept And Cases. Pearson Education International. Prentice Hall, Inc.

David, Fred R. 2006. Strategy Management. Ichsan Setiyo Budi
(Penterjemah). Manajemen

Strategi. Salemba Empat. Jakarta.

Dhany E Prasetyo. 2003. Analisis Faktor-Faktor Lingkungan Terhadap Keberhasilan Industri Kripik Tempe Di Sanan Kota Malang. Tesis Fakultas Ekonomi Pasca Sarjana. Universitas Brawijaya. Malang.

Fred R, David, 2006. Manajemen Strategis, Edisi Sepuluh; Salemba Empat, Jakarta

Kotler P. dan gary Armstrong, 1997. Principles of Marketing. Singapore: Hall Internatinal Editions

Lian Dwi Gerhana. 2006. Pengaruh Strategi Resource-Based dan Inovasi Terhadap Penciptaan Keunggulan Daya Saing Industri Kecil Bubuk Kayu Jati Di Kecamatan Kasiman Kabupaten Bojonegoro. Tesis Fakultas Eonomi Pasca Sarjana. Universitas Brawijaya. Malang.

Niode, Idris Yanto. 2012. Analisis Strategi Keunngulan bersaing (Comptitive Advantage) Sektor Usaha Kecil Menengah di Kota Gorontalo (Studi Industri Meubel di Kota Gorontalo). BISMA Jurnal Bisnis dan Manajemen Vol.4:2. Universitas Negeri Surabaya. Pp. 91-101

Niode, Idris Yanto, Mopangga Herwin. 2016. Manajemen Usaha (Produk Unggul Lokal Stik Jagung Ikan). Ideas Publishing. Gorontalo

Nurhajati. 2003. Analisi Faktor-Faktor yang Mempengaruhi Kinerja dan Keunggulan Bersaing Usaha Kecil yang Berorientasi Ekspor Di Jawa Timur. Disertasi Fakultas Ekonomi Pasca Sarjana. Universitas Brawijaya. Malang. 
Pono, Maat. 2008. Pengaruh Dinamika Lingkungan, Strategi Bersaing, dan Strategi Operasi Terhadap Kinerja Perusahaan (Studi pada Industri manufaktur di Sulawesi Selatan). Disertasi Fakultas Ekonomi Pasca Sarjana. Universitas Brawijaya. Malang.

Porter, Michael E. Competitive Advantage. 1993. Tim Binarupa Aksara (penterjemah).1996. Straetgi Bersaing, Strategi Menganalisis Industri dan Pesaing. Penerbit Erlangga. Jakarta.

Pramiyanti, Alila. 2008. Studi Kelayakan Bisnis Untuk UKM. Medpress. Yogyakarta.

Rangkuti Freddy, 1997, Teknik Membedah Kasus Bisnis, cetakan keempat belas 2006, Gramedia Pustaka Utama, Jakarta

Rangkuti, Freddy. 2005. Analisis SWOT Teknik Membedah Kasus Bisnis. Gramedia Pustaka Utama. Jakarta.

Rangkuti Freddy, 2009, Strategi Promosi Yang Kreatif, edisi pertama, cet. 1th, Gramedia Pustaka Utama, Jakarta

Suseno, Djoko. 2009. Pengaruh Strategi Keunggulan Bersaing, Sumber Daya Perusahaan dan Implementasi Strategi Generik Terhadap Kinerja Usaha Dengan Lingkungan Operasi Sebagai Variabel Moderating. Disertasi Fakultas Ekonomi Pasca Sarjana. Universitas Brawijaya. Malang.

Tripomo, Tedjo dan Udan. 2005. Management Strategic. Rekayasa sains. Bandung.

Umar, Husein. 2008. Strategic Management In Action. PT. Gramedia Pustaka Utama. Jakarta.
Wheelen, Thomas dan Hunger, David. 2004. Strategic Management Anda Business Policy. Ninth Edition. Pearson Prentice Hall, Inc.

Yunus, Hadi Sabari. 2010. Metodologi Penelitian Wilayah Kontemporer. Yogyakarta: Pustaka Pelajar.

Wikipedia. 2019. https://id.wikipedia.org/wiki/Goro ntalo (Diakses Tahun 2019) 